\title{
The Extremophilic Actinobacteria: From Microbes to Medicine
}

\author{
Martha Lok-Yung Hui ${ }^{1}$, Loh Teng-Hern Tan ${ }^{1,2}{ }^{\oplus}$, Vengadesh Letchumanan ${ }^{1}\left(\mathbb{D}\right.$, Ya-Wen He ${ }^{3}$, Chee-Mun Fang ${ }^{4}{ }^{\circledR}$, \\ Kok-Gan Chan $5,6,7, * \mathbb{D}$, Jodi Woan-Fei Law ${ }^{1, *}$ and Learn-Han Lee ${ }^{1, *(1)}$
}

1 Novel Bacteria and Drug Discovery Research Group (NBDD), Microbiome and Bioresource Research Strength (MBRS), Jeffrey Cheah School of Medicine and Health Sciences, Monash University Malaysia, Bandar Sunway 47500, Malaysia; lyhui1403@yahoo.com.hk (M.L.-Y.H.); loh.teng.hern@monash.edu (L.T.-H.T.); vengadesh.letchumanan1@monash.edu (V.L.)

2 Clinical School Johor Bahru, Jeffrey Cheah School of Medicine and Health Sciences, Monash University Malaysia, Johor Bahru 80100, Malaysia

3 State Key Laboratory of Microbial Metabolism, Joint International Research Laboratory of Metabolic and Developmental Sciences, School of Life Sciences and Biotechnology, Shanghai Jiao Tong University, Shanghai 200030, China; yawenhe@sjtu.edu.cn

4 Division of Biomedical Sciences, School of Pharmacy, University of Nottingham Malaysia, Semenyih, Selangor 43500, Malaysia; CheeMun.Fang@nottingham.edu.my

5 Division of Genetics and Molecular Biology, Institute of Biological Sciences, Faculty of Science, University of Malaya, Kuala Lumpur 50603, Malaysia

6 International Genome Centre, Jiangsu University, Zhenjiang 212013, China

7 Faculty of Applied Sciences, UCSI University, Kuala Lumpur 50600, Malaysia

* Correspondence: kokgan@um.edu.my (K.-G.C.); jodi.law1@monash.edu (J.W.-F.L.); lee.learn.han@monash.edu (L.-H.L.)

check for

Citation: Hui, M.L.-Y.; Tan, L.T.-H.; Letchumanan, V.; He, Y.-W.; Fang, C.-M.; Chan, K.-G.; Law, J.W.-F.; Lee, L.-H. The Extremophilic

Actinobacteria: From Microbes to Medicine. Antibiotics 2021, 10, 682. https://doi.org/10.3390/

antibiotics 10060682

Academic Editor: Jesus

Simal-Gandara

Received: 11 May 2021

Accepted: 3 June 2021

Published: 8 June 2021

Publisher's Note: MDPI stays neutral with regard to jurisdictional claims in published maps and institutional affiliations.

\section{Copyright: (c) 2021 by the authors.} Licensee MDPI, Basel, Switzerland. This article is an open access article distributed under the terms and conditions of the Creative Commons Attribution (CC BY) license (https:// creativecommons.org/licenses/by/ $4.0 /)$.

\begin{abstract}
Actinobacteria constitute prolific sources of novel and vital bioactive metabolites for pharmaceutical utilization. In recent years, research has focused on exploring actinobacteria that thrive in extreme conditions to unearth their beneficial bioactive compounds for natural product drug discovery. Natural products have a significant role in resolving public health issues such as antibiotic resistance and cancer. The breakthrough of new technologies has overcome the difficulties in sampling and culturing extremophiles, leading to the outpouring of more studies on actinobacteria from extreme environments. This review focuses on the diversity and bioactive potentials/medically relevant biomolecules of extremophilic actinobacteria found from various unique and extreme niches. Actinobacteria possess an excellent capability to produce various enzymes and secondary metabolites to combat harsh conditions. In particular, a few strains have displayed substantial antibacterial activity against methicillin-resistant Staphylococcus aureus (MRSA), shedding light on the development of MRSA-sensitive antibiotics. Several strains exhibited other prominent bioactivities such as antifungal, anti-HIV, anticancer, and anti-inflammation. By providing an overview of the recently found extremophilic actinobacteria and their important metabolites, we hope to enhance the understanding of their potential for the medical world.
\end{abstract}

Keywords: extremophile; actinobacteria; environment; bioactivity; metabolites

\section{Introduction}

Actinobacteria is a phylum of bacteria that comprises Gram-positive genera with high guanine and cytosine $(\mathrm{G}+\mathrm{C})$ content in their genomes and a few Gram-negative species [1,2]. Although actinobacteria are commonly present in terrestrial and aquatic ecosystems, they have a wide range of habitats, including extreme geographical locations such as deserts, hot springs, salt lakes, caves, and deep-sea [3-6]. In light of their abundance in such extreme environments accompanied by their well-known biosynthetic capabilities, scientists are interested in their metabolic versatility, discovering novel bioactive secondary metabolites, and their extracellular enzymes, which can be potentially propitious for pharmaceutical development [7-11]. 
Furthermore, actinobacteria have astonishing capabilities in adapting contaminated soil and efficiently decomposing organic materials such as hemicellulose and lignin through the actions of their metabolites [12]. Apparently, these bacteria can be bioindicators to toxic contaminants due to their higher sensitivity in detecting toxic elements [13]. Their unique tolerance to these contaminants accompanied by their degradation, biostimulation, and bioaugmentation abilities have enabled them to be great candidates for the bioremediation of heavy metals and organic pollutants [14-16]. Additionally, actinobacteria are incredible producers of agro-active and plant growth-promoting (PGP) compounds such as siderophores and indole acetic acid $[17,18]$. Actinobacteria have a major contribution to the agriculture industry whereby numerous strains (either single strains or in consortia) or their associated compounds have been applied as biofertilizers, biopesticides, and biological control agents [19-22]. The utilization of actinobacteria to manage plant diseases and pests that damage agricultural crops is effective, cost-saving, and eco-friendly, thus, they can substitute and mitigate the use of harmful chemical fertilizers and pesticides.

Actinobacteria can be categorized into two genera, Streptomyces and non-Streptomyces [23]. Streptomyces is the largest genus of Actinobacteria, and these bacteria are predominantly found in soil, but can also be present in various habitats such as marine/mangrove environments and plants [24-27]. Streptomycetes are unique filamentous Gram-positive bacteria that produce vegetative hyphae [28-30]. About $80 \%$ of clinically used antibiotics are derived from actinobacteria, in which a good number of them are isolated from the genus Streptomyces [19,31-33]. Astoundingly, streptomycetes remain as inexhaustible sources of antimicrobials to date [34,35]. In addition, about $17 \%$ of known active secondary metabolites are produced by this genus and many of them are of great medical significance [36-39]. For instance, Ivermectin, an antiparasitic agent is derived from Streptomyces avermitilis for treating lymphatic filariasis, was found to have a potent inhibitory effect on the growth of the formidable coronavirus disease 2019 (COVID-19) causative virus (SARSCoV-2) $[40,41]$. Besides, streptomycetes are also recognized as producers of antifungal, antitumor/anticancer, antioxidant, and antiviral agents [42-44].

In recent decades, the non-Streptomyces which is known as the rare actinobacteria (e.g., Micromonospora, Microbacterium, Jishengella, Salinispora, Saccharopolyspora, Sinomonas, Nocardiopsis, etc. [45-49]), has piqued the scientists' interest in discovering new unprecedented bioactive compounds produced by them. On the premise that extremophilic actinobacteria are a promising potential source of new drugs, we attempt to provide an overview of their bioprospecting aspects in this review.

\section{Types of Extremophiles}

Extremophiles are organisms that live in extreme habitats. They often have unique survival mechanisms to withstand harsh conditions such as high temperature, extreme $\mathrm{pH}$, salinity, pressure, and aridity [50,51]. Extremophiles can be divided into two broad categories, namely, the extremotolerant and the extremophilic. In some cases, the scientific community applied the term "extremophilic organism" to exclusively define organisms requiring one or more extreme growth conditions. In comparison, extremotolerant organisms are those that are able to tolerate one or more physicochemical parameters [52]. Extremophile-the suffix '-phile' originated from the Greek word 'philos', which conveys the meaning of 'love' and 'preference' of extreme environments [11,53]. Some examples of different types of extremophiles are listed in the following [54,55]: (a) thermophile-an organism that grows best at high temperatures and is commonly found in hot places such as the desert; (b) psychrophile-an organism that grows best at low temperatures; (c) halophile-an organism that thrives in habitats with high salt concentrations, such as sea and salt lakes; (d) alkaliphile-an organism that grows best in an alkaline environment; (e) acidophile - an organism that grows best in an acidic environment; (f) barophile-an organism that thrives at high-pressure conditions and is commonly found in deep-sea habitats; and ( $\mathrm{g}$ ) xerophile-an organism that grows best in an extremely arid area such as the desert. This review aims to collect information on actinobacteria present in various 
extreme environments and their potential to produce metabolites with bioactive properties such as antibacterial, antifungal, anticancer, and many more.

\section{Actinobacteria in Extreme Environments}

\subsection{Extremophilic Actinobacteria in Hot Springs}

Hot springs are usually formed by magma that heats the rainwater or underground water geothermally near the active volcanoes $[56,57]$. They are usually of low salinity $(<0.5 \%)$ and have a wide range of $\mathrm{pH}$ values ranging from 0.5 to 9 [58]. Hot springs are for balneotherapy or recreational purposes and are a breeding ground for extremophilic actinobacteria. A thermophile is a type of extremophile that survives growth optimally at a temperature of more than $50{ }^{\circ} \mathrm{C}$ [59]. To prevent the protein from aggregating at high temperatures, they have special 'heat shock' proteins called chaperones responsible for unfolding the denatured protein damaged by heat [60].

In a study by Liu and colleagues [61], sediments were taken from Tengchong County of Yunnan Province in China. Fifty-eight actinobacteria isolates were recovered from 10 hot springs distributed among Hehua, Rehai, and Ruidian, in which two novel genera, Thermoactinospora and Thermocatellispora, were also identified. The sampling sites' temperature and $\mathrm{pH}$ ranged from $62{ }^{\circ} \mathrm{C}$ to $99^{\circ} \mathrm{C}$, and 2.5 to 9.0 , respectively. It has been reported in another study that most of the thermophilic actinobacteria found in the Rehai were able to synthesize thermostable polymer-degrading enzymes which allow the bacteria to withstand the protein-denaturing temperature [62]. In particular, one of the strains produced cellulase, $\beta-1,4$-endoglucanase (Cel5A), which was highly tolerant to a high concentration of salt [62], and thus, indicates that the bacteria could be polyextremophilic and have a halotolerant property. Surprisingly, Liu, et al. [61] found that 53/58 strains were affiliated to 12 genera, namely, Actinomadura, Micromonospora, Microbispora, Micrococcus, Nocardiopsis, Nonomuraea, Promicromonospora, Pseudonocardia, Streptomyces, Thermoactinospora, Thermocatellispora, and Verrucosispora, in which several isolates exhibited antibacterial activities against various common pathogens including Acinetobacter baumannii, Micrococcus luteus, and Staphylococcus aureus. Furthermore, one strain, Micromonospora YIM 78104, demonstrated a particular broad antibacterial property. This study suggested a variety of actinobacterial species that are yet to be explored from hot springs, in which their secondary metabolites may contribute to the development of new antibiotics.

Gholami, et al. [56] isolated a novel strain, Kocuria rosea MG2, from the Ab-e-Siah spring in Ramsar City in Iran with the highest natural radioactivity. Ab-e-Siah spring is a radioactive hypothermal spring with a recorded radon concentration of $146.5 \mathrm{~Bq}$. 1-1 [63]. Its temperature ranged from 28 to $35^{\circ} \mathrm{C}$ with a $\mathrm{pH}$ value of 6.8 [56]. In this study, the MG2 strain was identified as Kocuria rosea by $16 \mathrm{~S}$ rRNA gene sequencing. Multiple stress tests were carried out, and the results were captivating. It was found that this strain was polyextremophile and able to survive under multiple stresses such as high levels of UV-C radiation, hydrogen peroxide, and desiccation. It also exhibited maximal growth at $\mathrm{pH}$ 9.2. It was suggested that carotenoids played an essential role in the photoprotective mechanism of the bacteria [56]. Carotenoids can absorb maxima at $450 \mathrm{~nm}$, which makes them an effective antioxidant [64]. This study provides a basis for advanced research on developing antioxidant agents with natural biomolecules.

Contrary to the traditional views and perceptions, the studies above have proven that in extremophile actinobacteria from hot springs, it is not necessary to be thermophilic. They may even be polyextremophilic, in which further investigation is required. Actinobacteria from hot springs can have various mechanisms to combat the harsh conditions of hot springs. The biometabolites they synthesized could be a potential new source of medicine such as antibiotics and antioxidants.

\subsection{Extremophilic Actinobacteria in Deserts}

Deserts cover about one-fifth of the Earth's surface [65]. Deserts are incredibly arid (average annual rainfall less than $25 \mathrm{~cm}$ ) [66] and have a wide range of temperatures and 
weather conditions with low nutrient status, making it difficult for most organisms to survive [67]. Although the general impression of a desert is patches of hot and empty land, some deserts are cold all year round. They can be classified into four categories: subtropical, cold, coastal, and semiarid [68]. Though deserts were once thought to be lifeless due to their extreme environments, recent studies have proven this perception is wrong. A wide range of actinobacteria are cultivatable in these places. To survive in such a harsh environment, living forms, including bacteria, need to have unique survival mechanisms to adapt to the extreme environment. Therefore, they tend to produce various interesting secondary metabolites which assist them in their survival.

Many studies have been carried out to investigate the actinobacteria isolated from deserts and analyze their bioactive potentials. Abenquines are new bioactive metabolites that Schulz, et al. [69] discovered. Streptomyces sp. strain DB634 was isolated from the soil taken from Salar de Tara of the Atacama Desert, Chile, which is known to be one of the driest places on earth with an average annual rainfall of about $15 \mathrm{~mm}$; every one square meter only receives a depth of $15 \mathrm{~mm}$ water each year [70]. It also has the highest level of ultraviolet radiation on earth [71]. For the above reasons, its soil has been compared to that of Mars. In the study, four abenquines (A-D) were then isolated from the fermentation broth of Streptomyces sp. strain DB634 and found to be structurally related to aminobenzoquinones. Other studies have revealed that benzoquinones possess antioxidant and anticancer properties in addition to anti-inflammatory effects [72]. Abenquines A and $\mathrm{D}$ demonstrated selective inhibition of phosphodiesterase type $4 \mathrm{~b}$ (PDE4B), which is known to upregulate CYLD expression, a key modulator in suppressing inflammatory reactions $[69,73]$. Hence, these two abenquines can be a potential source for developing a new anti-inflammatory agent for inflammatory diseases. Besides, inhibition of PDE4 downregulates the production of cyclic adenosine monophosphate (cAMP), which is the cardinal regulator of both the innate and adaptive immune response, and it is also capable of suppressing T-cell stimulating cytokines $[74,75]$. Therefore, abenquines could be an alternative therapeutic option for T-cell mediated autoimmune disorders such as celiac disease and rheumatoid arthritis, although more studies are warranted to understand its pharmaceutical applications.

Four types of ansamycin-type polyketides, the chaxamycins A-D (Table 1), were identified from the Streptomyces sp. strain C34 isolated from Salar de Tara of Atacama soil [76]. Ansamycin is a lipophilic antibiotic that possesses antitumor activity [76]. It exerts its activity by selectively inhibiting the heat shock protein (Hsp90) by interrupting its ATPase activity, which induces tumor cell death [76]. Its selective action against Hsp90 also leads to the degradation of proteins essential for cancer cells' survival [77]. Moreover, the increase of antibiotic-resistant bacteria has driven scientists towards the research for new antibiotics. Thus, the antimicrobial properties of chaxamycins A-D were evaluated with Staphylococcus aureus and Escherichia coli by the agar diffusion method. Chaxamycin $D$ exhibited a selectively high antibacterial activity against methicillin-resistant $S$. aureus (MRSA) and methicillin-sensitive S. aureus (MSSA), the majority with MIC values of less than $1.21 \mu \mathrm{g} / \mathrm{mL}$ [76]. This study exemplifies that actinobacteria isolated from deserts are promising bioprospecting resources for new antibiotics and cancer drugs.

Habitats with extreme aridity such as the Atacama Desert have drawn microbiologists' interest due to the variety of flora found there. The compounds synthesized by these florae are viewed as the scaffolds for new drugs. Wichner, et al. [78] discovered six novel glycosides-lentzeosides A-F from the Atacama Desert (Table 1), which demonstrated anti-HIV integrase activity. The soil samples were collected from a high-altitude location (>5000 m) where Lentzea sp. H45 was isolated. The compounds lentzeosides A-F produced by the strain were then tested for inhibitory activity against HIV-1 integrase at different concentrations [78]. HIV-1 integrase is a vital enzyme for completing the HIV viral replication cycle at the post-entry phase and, therefore, has been the target for antiretroviral drug development [69]. The three FDA-approved antiretroviral drugs, elvitegravir, raltegravir, and dolutegravir are all integrase strand transfer inhibitors [79]. Results showed that 
lentzeoside $\mathrm{C}, \mathrm{D}$, and $\mathrm{E}$ achieved $\mathrm{IC}_{50}$ values at 21,16 , and $21 \mu \mathrm{M}$, respectively, which were lower than lentzeoside A, B, and F. This indicates that lentzeoside C, D, and E exhibit a more potent inhibitory activity, whereas lentzeoside A, B, and F demonstrate a moderate inhibitory effect on HIV integrase [78]. Hence, this newly discovered group of lentzeoside is a good product for antiretroviral therapy.

Table 1. Summary of bioactivity of actinobacterial strains isolated from the Atacama Desert.

\begin{tabular}{|c|c|c|c|c|c|c|c|}
\hline Sampling Site & Strain & $\begin{array}{c}\text { Extremophilic } \\
\text { Properties }\end{array}$ & Sample Type & Bioactivity & Compound & $\mathrm{IC}_{50}$ or $\mathrm{MIC}$ & Reference \\
\hline $\begin{array}{l}\text { Salar de Tara of } \\
\text { the Atacama } \\
\text { Desert, Chile }\end{array}$ & $\begin{array}{l}\text { Streptomyces sp. } \\
\text { DB634 }\end{array}$ & Polyextremophilic & Desert soil & $\begin{array}{l}\text { Anti-inflammatory } \\
\text { activity via human } \\
\text { recombinant cyclic } \\
\text { AMP (cAMP)-specific } \\
\text { phosphodiesterase } \\
\text { (PDE-4B2) inhibition }\end{array}$ & $\begin{array}{c}\text { Abenquines A } \\
\text { and D }\end{array}$ & $\begin{array}{c}\mathrm{IC}_{50} \\
\text { Abenquines A: } \\
4.6 \pm 0.2 \mu \mathrm{M} ; \\
\text { Abenquines D: } \\
4.2 \pm 0.3 \mu \mathrm{M}\end{array}$ & [69] \\
\hline $\begin{array}{l}\text { Salar de Tara of } \\
\text { the Atacama } \\
\text { Desert, Chile }\end{array}$ & $\begin{array}{l}\text { Streptomyces sp. } \\
\text { C34 }\end{array}$ & Polyextremophilic & Desert soil & $\begin{array}{c}\text { Antibacterial activity } \\
\text { against E. coli, S. aureus } \\
\text { (MRSA and MSSA) } \\
\text { Antitumor } \\
\text { activity-inhibition of } \\
\text { Hsp90 }\end{array}$ & $\begin{array}{c}\text { ChaxamycinD } \\
\text { Chaxmycins } \\
\text { A-D }\end{array}$ & $\begin{array}{c}\text { MIC } \\
\text { E. coli and S. aureus: } \\
<1.21 \mu \mathrm{g} / \mathrm{mL} \\
\mathrm{IC}_{50} \\
\text { N.A. }{ }^{\mathrm{a}}\end{array}$ & [76] \\
\hline $\begin{array}{c}\text { At a } \\
\text { high-altitude } \\
\text { location } \\
(>5000 \mathrm{~m}) \text { in } \\
\text { Atacama Desert }\end{array}$ & Lentzea sp. H45 & Polyextremophilic & Desert soil & $\begin{array}{l}\text { Inhibition of } \\
\text { HIV-integrase }\end{array}$ & $\begin{array}{l}\text { Lentzeosides } \\
\text { A-F }\end{array}$ & $\begin{array}{c}\text { IC }_{50} \\
\text { Lentzeoside } \\
\text { A > } 100 \mu \mathrm{M} ; \\
\text { Lentzeoside } \\
\text { B > } 100 \mu \mathrm{M} ; \\
\text { Lentzeoside C: } \\
21 \mu \mathrm{M} \text {; Lentzeoside } \\
\text { D: } 16 \mu \mathrm{M} ; \\
\text { Lentzeoside E: } \\
21 \mu \mathrm{M} ; \text { Lentzeoside } \\
\text { F > } 100 \mu \mathrm{M}\end{array}$ & [78] \\
\hline $\begin{array}{l}\text { Saudi Arabian } \\
\text { desert }\end{array}$ & $\begin{array}{l}\text { Streptomyces sp. } \\
\text { DA3-7 }\end{array}$ & $\begin{array}{l}\text { Thermotolerant } \\
\text { (proposed) }\end{array}$ & Desert soil & $\begin{array}{c}\text { Antibacterial activity } \\
\text { against: } \\
\text { E. coli, } \\
\text { S. typhimurium, } \\
\text { S. aureus, } \\
\text { P. vulgaris, } \\
\text { P. aeruginosa, } \\
\text { E. faecalis, } \\
\text { K. pneumoniae } \\
\text { Antifungal activity } \\
\text { against: } \\
\text { C. albicans } \\
\text { S. cerevisiae } \\
\text { C. neoformans }\end{array}$ & $\begin{array}{l}\text { Pyridine-2,5- } \\
\text { diacetamide }\end{array}$ & $\begin{array}{c}\text { MIC } \\
\text { E. coli: } 31.25 \mu \mathrm{g} / \mathrm{mL} ; \\
\text { S. typhimurium, } S \text {. } \\
\text { aureus, P. vulagris, } P \text {. } \\
\text { aeruginosa, and } E \text {. } \\
\text { faecalis: } 62.5 \mu \mathrm{g} / \mathrm{mL} ; \\
\text { K. pneumoniae: } \\
125 \mu \mathrm{g} / \mathrm{mL} ; \\
\text { C. neoformans: } \\
\text { 31.25 } 2 \mathrm{~g} / \mathrm{mL} ; \mathrm{C} \text {. } \\
\text { albicans and } \\
\text { S. cerevisiae: } \\
62.5 \mu \mathrm{g} / \mathrm{mL}\end{array}$ & [80] \\
\hline
\end{tabular}

${ }^{\mathrm{a}}$ Not available.

Nithya, et al. [80] evaluated the antimicrobial activity of 134 actinobacterial isolates collected from the Saudi Arabian desert. Among these isolates, the ethyl acetate extract of Streptomyces sp. DA3-7 demonstrated a broad-spectrum antagonistic effect on various pathogens, including Pseudomonas aeruginosa, Staphylococcus aureus, Klebsiella pneumoniae, Enterococcus faecalis, Escherichia coli, Proteus vulgaris, and Salmonella typhimurium; as well as Fungi Candida albicans, Cryptococcus neoformans, and Saccharomyces cerevisiae. It is likely that Streptomyces sp. DA3-7 could be a thermotolerant bacterium as it was able to tolerate maxima at $40{ }^{\circ} \mathrm{C}$. It has been established that thermotolerant microbes achieve optimal growth at $40^{\circ} \mathrm{C}[81,82]$. Furthermore, the extract also displayed cytotoxic activity against the MCF-7 breast adenocarcinoma cell line $\left(\mathrm{IC}_{50}=85 \mu \mathrm{g} / \mathrm{mL}\right)$. The active compound, pyridine-2,5-diacetamide, was isolated from the crude extract, and it was found that MIC values of pyridine-2,5-diacetamide were the lowest against E. coli and C. neoformans (both $31.25 \mu \mathrm{g} / \mathrm{mL}$ ) (Table 1), which is lower than that of the standard therapeutic drugs ketoconazole $(50 \mu \mathrm{g} / \mathrm{mL})$ and streptomycin $(10 \mu \mathrm{g} /$ disc $)$, respectively [80].

\subsection{Extremophilic Actinobacteria in Deep-Sea Sediment}

The marine creatures commonly known to us are coastal ocean species, and most of the live forms in the deep sea remain enigmatic to humans. Most of this vast blue realm is 
unexplored, and only a small fraction of the ocean has been mapped [83]. The pressure, oxygen level, temperature, and nutrients of the deep-sea vary depending on the area. Nevertheless, in such an extreme environment where the pressure is immense, and no light can penetrate, certain groups of actinobacteria have acclimatized and demonstrated great biosynthetic capacity $[84,85]$. Research on deep-sea actinobacterial diversity is limited, which is often due to the difficulty of sampling. Thanks to the breakthrough of technologies, more unique species are brought to light.

Eighteen marine actinobacteria were isolated from seawater, corals, and echinoderms in Avilés Canyon, Spain. Samples were collected at a depth of 1500 to $4700 \mathrm{~m}$. As determined by $16 \mathrm{~S}$ rRNA sequencing, they mostly belonged to the genus Streptomyces, and the remaining were Pseudonocardia, Micromonospora, and Myceligenerans [86]. Cytotoxic assays of ethyl acetate extract of the strains against HeLa, a breast cell line, and HCT116, a human colon tumor cell line, were also carried out. The extracts of the two strains Streptomyces cyaneofuscatus M-157 and M-192 showed the highest cytotoxic activity against the cancer cells. Even more so, both extracts were still active even after dilution at 1:100. Both Streptomyces xiamenensis M186 and S. cyaneofuscatus M190 were also able to produce $\beta$-elemene, a compound that has been used to treat brain and breast cancer clinically $[87,88]$. Metabolite profiling analysis showed that three compounds, cosmomycin, daunomycin, and galtamycin which possess antitumor activity, were detected in the ethyl acetate extract of S. cyaneofuscatus M192 [86]. Besides, antibiotic assays with ethyl acetate extracts from different strains also showed potent antibacterial activity against a wide range of pathogens and fungi such as Gram-negative Escherichia coli, Micrococcus luteus, and Saccharomyces cerevisiae. Two of the strains, Micromonospora tulbaghiae M194 and Streptomyces halstedii M204, showed a moderate antifungal effect on S. cerevisiae [86]. Notably, only the strains of S. cyaneofuscatus produce compounds with antagonistic activity against antibiotic-resistant M. tuberculosis. Based on these findings, these strains' extract exerted good antimicrobial activity towards several pathogens and cytotoxic effect against HeLa and HCT116 cancer cells (Table 2). In short, this study presented a preliminary finding that marine actinobacteria can be a great potential source of antifungal and anticancer agents other than antibacterial. Therefore, it will be worthy of investigating the compounds responsible for these observed bioactivities.

Unarguably, the active metabolites of actinobacteria are indeed a great source of new drugs. Nevertheless, the application of elicitor to the culture medium is crucial to stimulate the stress response for metabolites' production. Factors such as type, concentration, and duration of exposure of the elicitor are also cardinal to determine the production of the metabolites [89]. $\mathrm{Xu}$, et al. [90] evaluated fifty actinobacteria strains cultivated from deepsea at various sites where the depths ranged from $150 \mathrm{fsw}$ to $2790 \mathrm{fsw}$. Nineteen of the isolates belonged to the genus Streptomyces while the others were rare actinobacteria. Notably, 27 strains showed positive antimicrobial activity, whereby the activity of 15 strains was enhanced by the elicitor lanthanum chloride $\left(\mathrm{LaCl}_{3}\right)(2 \mathrm{mM})$ while 11 of them were attenuated by it. For instance, Streptomyces sp. R818 exerted a potent antifungal (MIC of $25 \mu \mathrm{g} / \mathrm{mL}$ ) and synthesized antimycin-like metabolite, urauchimycin D, only when $\mathrm{LaCl}_{3}$ was used as the elicitor. Until now, metronidazole or vancomycin remains the first-line therapy for $C$. difficile infection [91]. Interestingly, the antibacterial activity against C. difficile was detected in Salinispora M864 after the fermentation with $\mathrm{LaCl}_{3}$. It exerted its activity with an MIC value $(0.125 \mu \mathrm{g} / \mathrm{mL})$ four times less than that of metronidazole and vancomycin $(0.5 \mu \mathrm{g} / \mathrm{mL})$ [90]. Herein, a pertinent elicitor is essential for obtaining the desired bioactivity effectively. The significant bioactivities of the strains are summarized in Table 2. 
Table 2. Bioactivity of actinobacterial strains isolated from the deep-sea environment.

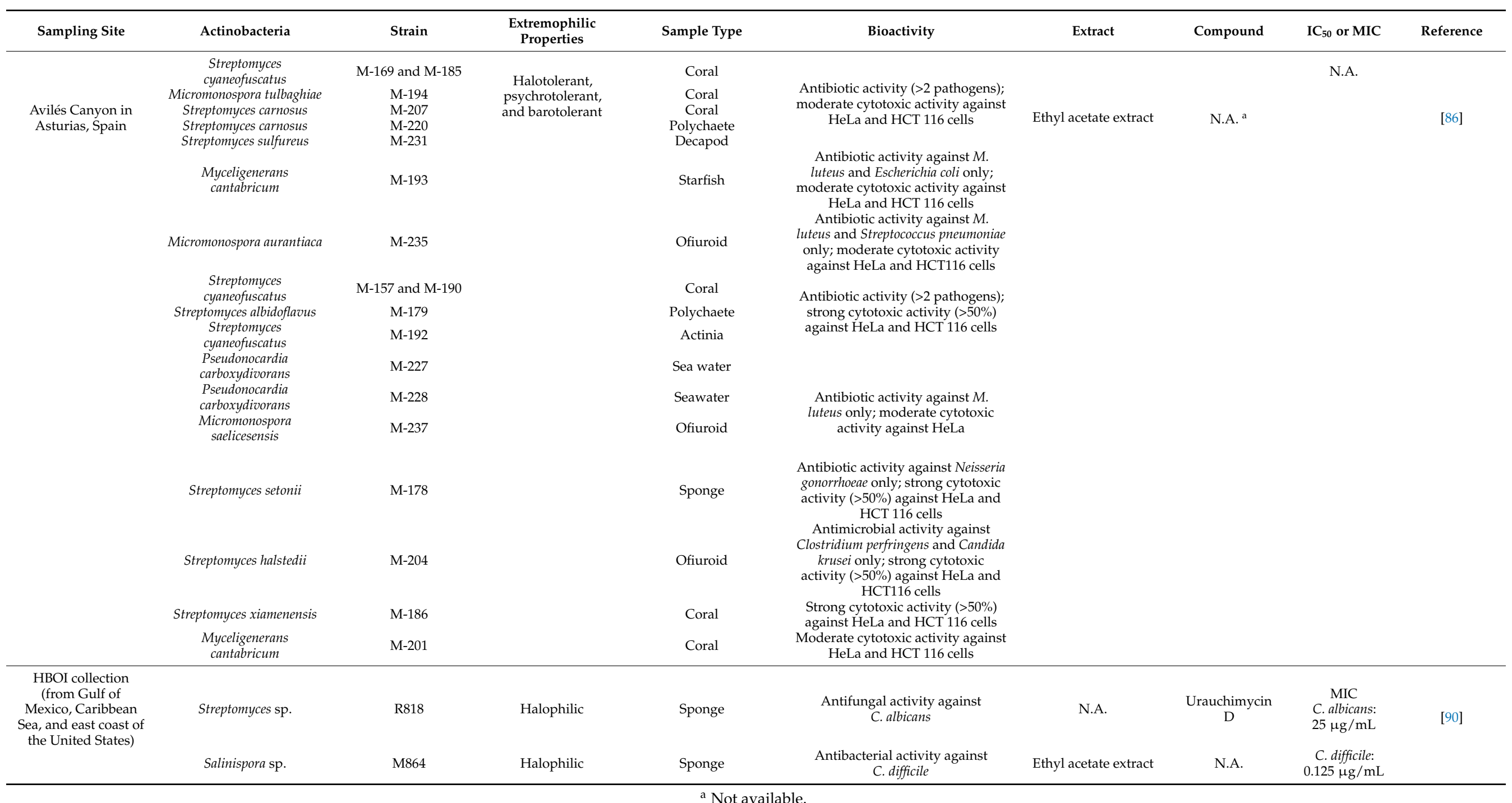




\subsection{Extremophilic Actinobacteria in Caves}

There is an abounding number of caves on earth, and the most common types are the limestone, calcareous, and basaltic caves [92]. Depending on the types of caves, the processes of formation range widely. For instance, stone caves are formed by erosion and weathering over millions of years [93], while limestone caves are formed by natural acid dissolving the stone [94]. Some caves, such as moonmilk caves, are formed by microbial degradation of carbonate [92].

Moonmilk has long been regarded as a medication. From the 16th to 19th centuries, moonmilk was used as a medication to treat calcinosis and cardialgia, according to swiss naturalist Conrad Gesner (1516-1555) [95]. Though not all moonmilk caves' formation involves microbial activity, many do hold a wide range of microbes such as bacteria, especially streptomycetes, fungi, and algae in markedly high density [92,96]. Forty isolates were obtained by Adam, et al. [97] from the moonmilk cave Grotte des Collemboles, Comblain-au-Pont located in Belgium. These isolates were associated with the genera Agromyces, Amycolatopsis, Kocuria, Micrococcus, Micromonospora, Nocardia, Rhodococcus, and Streptomyces. The extremophiles have to develop unique survival strategies that allow them to dwell in the moonmilk cave exclusively [92]. This characteristic is evidenced by the highly territory-selective behavior of the isolates. For instance, $58 \%$ of the isolates in pure cultures died after the second round of inoculation in the study. It is likely to be caused by the absence of neighboring cultures and the substances emanated by them, a common mutualistic survival strategy adopted by organisms dwelling in an oligotrophic environment [97]. The antibacterial activity of the isolates was evaluated via the crossstreak method. Overall, the isolates showed a more potent inhibitory activity against Gram-positive bacteria than Gram-negative bacteria. Among all isolates, one extremely rare actinobacterium Amycolatopsis sp. MMun171 (actinobacterial abundancy <0.001\%) exhibited the most robust antibacterial activities against both Gram-positive and Gramnegative microbes (E. coli, P. aeruginosa, Citrobacter freundii, K. pneumoniae, Bacillus subtilis, S. aureus, and M. luteus) under all culture conditions [97] (Table 3). This finding rekindles the hope of researchers to search for novel antibiotics from extremophiles in unique niches. However, since many isolates (58\%) were lost during the purification process in the first study, it is necessary to mimic their environmental niche with specific growth factors to increase microbial growth.

A wide diversity of taxonomy, including some rare taxa, were isolated from the Shuanghe Karst Cave in Guizhou province in China. It is the longest cave in Asia, with a total cave passage of $130 \mathrm{~km}$ [98]. Karst caves are formed by the slow dissolution of limestone, gypsum, and dolomite by acid rainwater [99]. The cave is an extreme habitat because it is dim, humid, and cold but is also oligotrophic as a minimal source of organic material is present. A total of 45 isolates categorized into 23 species and 7 genera in which most of them were Streptomyces (52\%), followed by Actinoplanes (13\%), Nocardioides, Agromyces, Rhodococcus, Oerskovia, and Micromonospora (all $>1 \%$ ) were investigated by Long, et al. [100]. The antimicrobial activity of these isolates was screened, and 16 out of 45 isolates showed inhibitory activity against at least one of the tested pathogens E. coli, $S$ aureus, and Botrytis cinerea. Besides, Streptomyces badius S142 and Actinoplanes friuliensis S761 displayed the strongest activity against all pathogens. This result is in line with a previous study in which an amphomycin-like new lipopeptide compound, friulimicins, derived from $A$. friuliensis demonstrated an intense antibiotic activity, even against multidrugresistant strains [101]. In short, these studies have exemplified the high diversity of rare actinobacteria in caves, and the bioactive compounds produced by these extremophiles in these particular niches do offer a promising means to tackle the antibiotic resistance crisis. 
Table 3. Summary of bioactivity of actinobacterial strains isolated from caves.

\begin{tabular}{|c|c|c|c|c|c|}
\hline Sampling Site & Actinobacteria & Strain & Sample Type & Bioactivity & Reference \\
\hline \multirow{6}{*}{$\begin{array}{l}\text { Moonmilk cave Grotte } \\
\text { des Collemboles, } \\
\text { Belgium }\end{array}$} & Amycolatopsis sp. & MMun171 & \multirow{3}{*}{\multicolumn{2}{|c|}{$\begin{array}{l}\text { Antibacterial activity against } E \text {. } \\
\text { coli, P. aeruginosa, C. freundii, K. } \\
\text { pneumoniae, } B . \text { subtilis, } S . \text { aureus, } \\
\text { and } M . \text { luteus }\end{array}$}} & \multirow{6}{*}{ [97] } \\
\hline & Kocuria rhizophila & MMun160 & & & \\
\hline & & & & & \\
\hline & & MMun141 & & Strong antibacterial activity, & \\
\hline & Streptomyces sp. & MMun146 & & particularly against $B$. subtilis, $S$. & \\
\hline & & MMun156 & & aureus, and M. luteus & \\
\hline \multirow{2}{*}{$\begin{array}{c}\text { Shuanghe Karst Cave, } \\
\text { Guizhou province, } \\
\text { China }\end{array}$} & Streptomyces badius & S142 & Bat guano & \multirow[b]{2}{*}{$\begin{array}{c}\text { Antimicrobial activity against } E \text {. } \\
\text { coli, S. aureus, B. cinerea }\end{array}$} & \multirow[t]{2}{*}{ [100] } \\
\hline & $\begin{array}{l}\text { Actinoplanes } \\
\text { friuliensis }\end{array}$ & S761 & Rock soil & & \\
\hline
\end{tabular}

\subsection{Extremophilic Actinobacteria in Salt Lakes}

Salt Lakes are one of the unique niches that have drawn the interest of scientists in recent years. A salt flat is the basis of the formation of salt lakes. The salt flat is usually formed in arid areas where evaporation outpaces precipitation, leaving the salt behind [102]. When there is open water such as rain and stream entering the landscape that dissolves the salt precipitate, a salt lake is formed [102]. Interestingly, they display a broad diversity in their sedimentary process, morphology, hydrology, and ecosystems [103]. Depending on the content of the lakes, their composition of ecosystems varies greatly. Given their high saturation of ions, microbial dwellers often develop unique strategies to cope with extreme conditions.

Generally, the resistance mechanism and DNA-repair system of extremophilic bacteria in the salt lake were investigated by Albarracín, et al. [104]. A group of bacteria belonging to the Acinetobacter genus was obtained from the high-altitude Andean lakes (HAAL), Puna Desert. HAALs is a collection of salt lakes located at the Dry Central Andes where UV-B radiation is exceptionally high. It is also characterized by high arsenic toxicity, salinity, extreme temperatures, and $\mathrm{pH}$ [105]. The potent photo-repair ability of the extremophiles might be due to a particular gene HQ443199 of Ver 3, which encodes class-I photolyase responsible for repairing UV-induced DNA lesions in cis-syn cyclobutane pyrimidine dimer (CDP) and pyrimidine (6-4) pyrimidone photoproducts (6-4PPs), which are commonly damaged by high UV-intensity [106]. A study by Wu et al. [107] revealed a rich diversity of actinobacteria (Actinomycetes, Bifidobacterium, Corynebacterium, etc.) present in the sediments of two salt lakes, Qaidam Lake and Qinghai Lake, China. Nonetheless, the coping mechanism of these extremophilic actinobacteria requires further investigation.

In extreme environments where nutrients and resources are scarce, organisms tend to produce antimicrobial secondary metabolites to inhibit other competitors' growth for survival. Therefore, niches such as HAALs are storehouses of potential sources of antibiotics. The extremophilic profile and antimicrobial activity of actinobacteria in HAAL are investigated in a study conducted by Rasuk, et al. [105]. Fifty-one isolates were from various lakes of HAALs and were found to be members of the following genera: Arthrobacter, Blastococcus, Brevibacterium, Citrococcus, Kocuria, Microbacterium, Micrococcus, Micromonospora, Nesterenkonia, Rhodococcus, as well as Streptomyces. Their polyextremophilic properties were evaluated. Results showed that all 51 isolates demonstrated high resistance to UVB radiation. Furthermore, several isolates were able to tolerate and grow in an extremely high $\mathrm{pH}$ value of 12, indicating that they are incredibly alkaliphilic. Regarding their halotolerant property, all strains could tolerate $5 \% \mathrm{NaCl}$, but only 21 of the isolates were able to tolerate up to $25 \% \mathrm{NaCl}$. The antagonistic activities were studied against S. aureus, E. coli, Bacillus sp., E. faecalis, and two fungi species (Rhodotorula sp.). The data showed that all isolates displayed antagonistic activity against at least one of the tested pathogens (Table 4), suggesting inhibitory activity was relatively common among extremophiles in salt lakes 
such as HAALs. Especially, those of Streptomyces sp., Microbacterium sp., and Micrococcus sp. are capable of producing cytotoxic compounds against other organisms.

Table 4. Summary of bioactivity of actinobacterial strains isolated from salt lakes.

\begin{tabular}{|c|c|c|c|c|}
\hline Sampling Site & Actinobacteria & Sample Type & Bioactivity & Reference \\
\hline $\begin{array}{c}\text { Laguna Diamante, } \\
\text { Antofalla, Laguna Santa } \\
\text { Maria, Laguna Socomp, } \\
\text { Tolar Grande, and Salina } \\
\text { Grande, Argentina }\end{array}$ & $\begin{array}{c}\text { Actinobacterial strains of } \\
11 \text { genera Streptomyces, } \\
\text { Micrococcus, } \\
\text { Microbacterium, } \\
\text { Nesterenkonia, Kocuria, } \\
\text { Rhodococcus, Arthrobacter, } \\
\text { Micromonospora, } \\
\text { Blastococcus, } \\
\text { Brevibacterium, and } \\
\text { Citricoccus }\end{array}$ & $\begin{array}{l}\text { Soil, stromatolite, } \\
\text { sediment, water, and } \\
\text { flamingo feces }\end{array}$ & $\begin{array}{c}\text { Antibacterial activity } \\
\text { against } E \text {. coli, Bacillus, E. } \\
\text { faecalis, S. aureus, and } \\
\text { Rhodotorula sp. (at least } 1 \text { ) }\end{array}$ & [105] \\
\hline
\end{tabular}

Undoubtedly, salt lakes are a cradle for polyextremophiles and hold great potential for pharmaceutical applications. The actinobacteria obtained from HAALs are highly UVresistant and exhibit good antimicrobial activity. The UV-resistance and DNA-regulatory proteins are potentially beneficial to the development of antioxidants and, therefore, should be further investigated.

\section{Discussion}

Based on the different extreme environments discussed in this review, deserts and the deep sea are the most favorable environments for the isolation of bioactive actinobacteria. Compounds with potential applications in medicine have been yielded from these two habitats. One of the reasons is their high abundance in these habitats. Actinobacteria has a dominant diversity and distribution in arid areas [108], and it is the most dominant phylum (72 to 88\%) in the Atacama Desert [109]. Similarly, it has been suggested that actinobacteria make up to about $10 \%$ of the bacteria colonizing aggregates in the sea, and their antagonistic activity is significant for their survival [110]. Besides, hot springs posed another excellent source for the isolation of bioactive thermophilic actinobacteria based on the literature findings. However, the research on extremophilic actinobacteria's medical applications from salt lakes was thus far minimal. More research is needed as salt lakes are potentially an excellent source for beneficial bioactive compounds.

For most studies, it is anticipated that future research scope should identify compounds responsible for the observed bioactivities. A typical approach to extract and purify the bioactive compounds from the bacteria would be through bioassay-guided fractionation [111-113]. With the chromatography separation techniques, pure compound isolation can be achieved following elucidation of compound structure [114,115].

Additionally, whole-genome sequencing via next-generation sequencing technology (NGS) can also provide means for evaluating the bacteria's bioactive capability by studying the biosynthetic gene cluster related to the compounds [116-118]. In particular, the streptomycetes possessed a prolific potential to synthesize a significant number of valuable secondary metabolites. It has been reported that the genome of the Streptomyces spp. can carry more than 20 to 30 biosynthetic gene clusters affiliated with secondary metabolite production [3,119-121]. By utilizing the genome sequencing technique and bioinformatics software, the biosynthetic gene clusters of many actinobacteria can thus be identified [122-125]. A simple illustration is detecting the gene cluster encoding the biosynthesis of ansamycin compounds in the genome sequence of Streptomyces sp. LZ35 [126]. The availability of NGS offers accurate results, which pushes forward the sequencing capacity at an affordable price. As more and more actinobacteria are discovered from the aforementioned special niches, discovering new bioactive compounds can also be accomplished through a genomic approach. 


\section{Conclusions}

In conclusion, actinobacteria present in extreme environments are great resources that can contribute to microbial drug discovery. Many studies have proven the bioactive potential of these extremophilic actinobacteria. Nevertheless, further in-depth studies are required to explore the bioactive capabilities of these extremophilic actinobacteria. With this, extremophilic actinobacteria represent an alternative rich source of bioactive compounds that can be harvested to develop novel medicines.

Author Contributions: M.L.-Y.H. performed the literature search and data collection. The manuscript was written by M.L.-Y.H., J.W.-F.L., and L.-H.L. The manuscript was reviewed and edited by L.T.-H.T., V.L., Y.-W.H., C.-M.F., K.-G.C., L.-H.L. and J.W.-F.L. conceptualized the project. All authors have read and agreed to the published version of the manuscript.

Funding: This work was supported by SEED Funding from Microbiome and Bioresource Research Strength (MBRS), Jeffrey Cheah School of Medicine and Health Sciences (Vote Number: MBRS/JCSMHS/02/2020), JCSMHS Strategic Grant 2021 (Grant Code: STG-000051), University of Malaya Research Grant (FRGS grant to K-GC grant no: FP022-2018A), and Fundamental Research Grant Scheme (FRGS/1/2019/SKK08/MUSM/02/7).

Acknowledgments: This work was inspired by the Jeffrey School of Medicine and Health Sciences "Scholarly Intensive Program (SIP)" at Monash University Malaysia.

Conflicts of Interest: The authors declare no conflict of interest.

\section{References}

1. Law, J.W.F.; Letchumanan, V.; Tan, L.T.H.; Ser, H.L.; Goh, B.H.; Lee, L.H. Editorial: The rising of "Modern Actinobacteria" era. Prog. Microbes Mol. Biol. 2020, 3, a0000064. [CrossRef]

2. Verma, M.; Lal, D.; Kaur, J.; Saxena, A.; Kaur, J.; Anand, S.; Lal, R. Phylogenetic analyses of phylum Actinobacteria based on whole genome sequences. Res. Microbiol. 2013, 164, 718-728. [CrossRef]

3. Law, J.W.-F.; Tan, K.-X.; Wong, S.H.; Ab Mutalib, N.-S.; Lee, L.-H. Taxonomic and characterization methods of Streptomyces: A review. Prog. Microbes Mol. Biol. 2018, 1, a0000009. [CrossRef]

4. Lee, L.-H.; Cheah, Y.-K.; Sidik, S.M.; Ab Mutalib, N.-S.; Tang, Y.-L.; Lin, H.-P.; Hong, K. Molecular characterization of Antarctic actinobacteria and screening for antimicrobial metabolite production. World J. Microbiol. Biotechnol. 2012, 28, 2125-2137. [CrossRef]

5. Qin, S.; Li, W.-J.; Dastager, S.G.; Hozzein, W.N. Actinobacteria in special and extreme habitats: Diversity, function roles, and environmental adaptations. Front. Microbiol. 2016, 7, 1415. [CrossRef] [PubMed]

6. Rangseekaew, P.; Pathom-Aree, W. Cave actinobacteria as producers of bioactive metabolites. Front. Microbiol. 2019, 10, 387. [CrossRef] [PubMed]

7. Law, J.W.-F.; Ser, H.-L.; Duangjai, A.; Saokaew, S.; Bukhari, S.I.; Khan, T.M.; Ab Mutalib, N.-S.; Chan, K.-G.; Goh, B.-H.; Lee, L.-H. Streptomyces colonosanans sp. nov., a novel actinobacterium isolated from Malaysia mangrove soil exhibiting antioxidative activity and cytotoxic potential against human colon cancer cell lines. Front. Microbiol. 2017, 8, 877. [CrossRef] [PubMed]

8. Lee, L.-H.; Zainal, N.; Azman, A.-S.; Eng, S.-K.; Goh, B.-H.; Yin, W.-F.; Ab Mutalib, N.-S.; Chan, K.-G. Diversity and antimicrobial activities of actinobacteria isolated from tropical mangrove sediments in Malaysia. Sci. World J. 2014, 2014, 698178. [CrossRef]

9. Lee, L.-H.; Chan, K.-G.; Stach, J.; Wellington, E.M.; Goh, B.-H. The search for biological active agent (s) from actinobacteria. Front. Microbiol. 2018, 9, 824. [CrossRef]

10. Stennett, H.L.; Tiwari, K.; Williams, S.E.; Curnow, P.; Race, P.R. The extremophilic pharmacy: Drug discovery at the limits of life. In Biotechnological Applications of Extremophilic Microorganisms; De Gruyter: Berlin, Germany, 2020; pp. 43-72.

11. Giddings, L.-A.; Newman, D.J. Bioactive Compounds from Extremophiles. In Bioactive Compounds from Extremophiles: Genomic Studies, Biosynthetic Gene Clusters, and New Dereplication Methods; Springer International Publishing: Cham, Switzerland, 2015; pp. $1-47$.

12. Chadlia, H.; Fatma, A.; Atef, J. Actinobacteria: A promising source of enzymes involved in lignocellulosic biomass conversion. Adv. Biotech. Microbiol. 2019, 13, 555874.

13. Madrova, P.; Vetrovsky, T.; Omelka, M.; Grunt, M.; Smutna, Y.; Rapoport, D.; Vach, M.; Baldrian, P.; Kopecky, J.; SagovaMareckova, M. A short-term response of soil microbial communities to cadmium and organic substrate amendment in long-term contaminated soil by toxic elements. Front. Microbiol. 2018, 9, 2807. [CrossRef]

14. Olajuyigbe, F.M.; Ehiosun, K.I. Assessment of crude oil degradation efficiency of newly isolated actinobacteria reveals untapped bioremediation potentials. Bioremediation J. 2016, 20, 133-143. [CrossRef]

15. Polti, M.A.; Aparicio, J.D.; Benimeli, C.S.; Amoroso, M.J. Simultaneous bioremediation of Cr (VI) and lindane in soil by actinobacteria. Int. Biodeterior. Biodegrad. 2014, 88, 48-55. [CrossRef]

16. Rathore, D.S.; Sheikh, M.; Singh, S.P. Marine Actinobacteria: New Horizons in Bioremediation. In Recent Developments in Microbial Technologies; Prasad, R., Kumar, V., Singh, J., Upadhyaya, C.P., Eds.; Springer: Singapore, 2021; pp. 425-449. 
17. Anwar, S.; Ali, B.; Sajid, I. Screening of rhizospheric actinomycetes for various in-vitro and in-vivo plant growth promoting (PGP) traits and for agroactive compounds. Front. Microbiol. 2016, 7, 1334. [CrossRef]

18. Anilkumar, R.R.; Edison, L.K.; Pradeep, N. Exploitation of fungi and actinobacteria for sustainable agriculture. In Microbial Biotechnology; Patra, J.K., Vishnuprasad, C.N., Das, G., Eds.; Springer: Singapore, 2017; pp. 135-162.

19. Law, J.W.-F.; Ser, H.-L.; Khan, T.M.; Chuah, L.-H.; Pusparajah, P.; Chan, K.-G.; Goh, B.-H.; Lee, L.-H. The potential of Streptomyces as biocontrol agents against the rice blast fungus, Magnaporthe oryzae (Pyricularia oryzae). Front. Microbiol. 2017, 8, 3. [CrossRef]

20. Zamoum, M.; Goudjal, Y.; Sabaou, N.; Barakate, M.; Mathieu, F.; Zitouni, A. Biocontrol capacities and plant growth-promoting traits of endophytic actinobacteria isolated from native plants of Algerian Sahara. J. Plant Dis. Prot. 2015, 122, 215-223. [CrossRef]

21. Jayakumar, J. Streptomyces avermitilis as a biopesticide for the management of root knot nematode, Meloidogyne incognita in tomato. Karnataka J. Agric. Sci. 2009, 22, 564-566.

22. Xiong, Y.-W.; Gong, Y.; Li, X.-W.; Chen, P.; Ju, X.-Y.; Zhang, C.-M.; Yuan, B.; Lv, Z.-P.; Xing, K.; Qin, S. Enhancement of growth and salt tolerance of tomato seedlings by a natural halotolerant actinobacterium Glutamicibacter halophytocola KLBMP 5180 isolated from a coastal halophyte. Plant Soil 2019, 445, 307-322. [CrossRef]

23. Hu, D.; Sun, C.; Jin, T.; Fan, G.; Mok, K.M.; Li, K.; Lee, S.M.-Y. Exploring the potential of antibiotic production from rare actinobacteria by whole-genome sequencing and guided MS/MS analysis. Front. Microbiol. 2020, 11, 1540. [CrossRef]

24. Anandan, R.; Dharumadurai, D.; Manogaran, G.P. Anandan, R.; Dharumadurai, D.; Manogaran, G.P. An introduction to actinobacteria. In Actinobacteria-Basics and Biotechnological Applications; IntechOpen: Rijeka, Croatia, 2016.

25. Law, J.W.-F.; Pusparajah, P.; Ab Mutalib, N.-S.; Wong, S.H.; Goh, B.-H.; Lee, L.-H. A review on mangrove actinobacterial diversity: The roles of streptomyces and novel species discovery. Prog. Microbes Mol. Biol. 2019, 2, a0000024. [CrossRef]

26. Lee, L.-H.; Law, J.W.-F.; Khan, T.M.; Chan, K.-G.; Ab Mutalib, N.-S.; Goh, B.-H. IDDF2019-ABS-0323 Unveiling the Anti-Colon Cancer Potential of Sarawak Mangrove-Derived Novel Streptomycetes. Gut 2019, 68, A42-A43.

27. Kemung, H.M.; Tan, L.T.-H.; Chan, K.-G.; Ser, H.-L.; Law, J.W.-F.; Lee, L.-H.; Goh, B.-H. Antioxidant activities of Streptomyces sp. strain MUSC 14 from mangrove forest soil in Malaysia. BioMed Res. Int. 2020, 2020, 6402607. [CrossRef]

28. Ser, H.-L.; Tan, L.T.-H.; Law, J.W.-F.; Chan, K.-G.; Duangjai, A.; Saokaew, S.; Pusparajah, P.; Ab Mutalib, N.-S.; Khan, T.M.; Goh, B.-H. Focused review: Cytotoxic and antioxidant potentials of mangrove-derived Streptomyces. Front. Microbiol. $2017,8,2065$. [CrossRef]

29. Ser, H.-L.; Law, J.W.-F.; Chaiyakunapruk, N.; Jacob, S.A.; Palanisamy, U.D.; Chan, K.-G.; Goh, B.-H.; Lee, L.-H. Fermentation conditions that affect clavulanic acid production in Streptomyces clavuligerus: A systematic review. Front. Microbiol. 2016, 7, 522. [CrossRef]

30. Tan, L.T.-H.; Chan, K.-G.; Chan, C.K.; Khan, T.M.; Lee, L.-H.; Goh, B.-H. Antioxidative potential of a Streptomyces sp. MUM292 isolated from mangrove soil. BioMed Res. Int. 2018, 2018, 4823126. [CrossRef] [PubMed]

31. Law, J.W.-F.; Ser, H.-L.; Ab Mutalib, N.-S.; Saokaew, S.; Duangjai, A.; Khan, T.M.; Chan, K.-G.; Goh, B.-H.; Lee, L.-H. Streptomyces monashensis sp. nov., a novel mangrove soil actinobacterium from East Malaysia with antioxidative potential. Sci. Rep. 2019, 9, 1-18.

32. Lee, L.-H.; Zainal, N.; Azman, A.-S.; Eng, S.-K.; Ab Mutalib, N.-S.; Yin, W.-F.; Chan, K.-G. Streptomyces pluripotens sp. nov., a bacteriocin-producing streptomycete that inhibits meticillin-resistant Staphylococcus aureus. Int. J. Syst. Evol. Microbiol. 2014, 64, 3297-3306. [CrossRef] [PubMed]

33. Hopwood, D.A. Streptomyces in Nature and Medicine: The Antibiotic Makers; Oxford University Press: New York, NY, USA, 2007.

34. Karpiński, T.M. Marine macrolides with antibacterial and/or antifungal activity. Mar. Drugs 2019, 17, 241. [CrossRef]

35. Cheah, Y.-K.; Lee, L.-H.; Chieng, C.; Catherine, C.-Y.C.; Wong, V.-L.C.M. Isolation, identification and screening of actinobacteria in volcanic soil of deception island (the Antarctic) for antimicrobial metabolites. Pol. Polar Res. 2015, 36, 67-78. [CrossRef]

36. Harir, M.; Bendif, H.; Bellahcene, M.; Fortas, Z.; Pogni, R. Streptomyces Secondary Metabolites; IntechOpen: London, UK, 2018; pp. 99-122.

37. Kemung, H.M.; Tan, L.T.-H.; Chan, K.-G.; Ser, H.-L.; Law, J.W.-F.; Lee, L.-H.; Goh, B.-H. Investigating the antioxidant potential of Streptomyces sp. MUSC 11 from mangrove soil in Malaysia. Prog. Drug Discov. Biomed. Sci. 2019, 2, a0000033. [CrossRef]

38. Tan, L.T.-H.; Chan, K.-G.; Khan, T.M.; Bukhari, S.I.; Saokaew, S.; Duangjai, A.; Pusparajah, P.; Lee, L.-H.; Goh, B.-H. Streptomyces sp. MUM212 as a source of antioxidants with radical scavenging and metal chelating properties. Front. Pharmacol. 2017, 8, 276. [CrossRef]

39. Lee, L.-H.; Goh, B.-H.; Chan, K.-G. Actinobacteria: Prolific producers of bioactive metabolites. Front. Microbiol. 2020, 11, 1612. [CrossRef]

40. Caly, L.; Druce, J.D.; Catton, M.G.; Jans, D.A.; Wagstaff, K.M. The FDA-approved Drug Ivermectin inhibits the replication of SARS-CoV-2 in vitro. Antivir. Res. 2020, 104787. [CrossRef] [PubMed]

41. Fox, L.M. Ivermectin: Uses and impact 20 years on. Curr. Opin. Infect. Dis. 2006, 19, 588-593. [CrossRef] [PubMed]

42. Tan, L.T.-H.; Lee, L.-H.; Goh, B.-H. The bioprospecting of anti-Vibrio Streptomyces species: Prevalence and applications. Prog. Microbes Mol. Biol. 2019, 2, a0000034. [CrossRef]

43. Sacramento, D.R.; Coelho, R.R.R.; Wigg, M.D.; Linhares, L.F.d.T.L.; dos Santos, M.G.M.; Semêdo, L.T.d.A.S.; da Silva, A.J.R. Antimicrobial and antiviral activities of an actinomycete (Streptomyces sp.) isolated from a Brazilian tropical forest soil. World $J$. Microbiol. Biotechnol. 2004, 20, 225-229. [CrossRef] 
44. Ser, H.-L.; Yin, W.-F.; Chan, K.-G.; Khan, T.M.; Goh, B.-H.; Lee, L.-H. Antioxidant and cytotoxic potentials of Streptomyces gilvigriseus MUSC $26^{\mathrm{T}}$ isolated from mangrove soil in Malaysia. Prog. Microbes Mol. Biol. 2018, 1, a0000002. [CrossRef]

45. Azman, A.-S.; Othman, I.; Velu, S.S.; Chan, K.-G.; Lee, L.-H. Mangrove rare actinobacteria: Taxonomy, natural compound, and discovery of bioactivity. Front. Microbiol. 2015, 6, 856. [CrossRef]

46. Azman, A.-S.; Othman, I.; Fang, C.-M.; Chan, K.-G.; Goh, B.-H.; Lee, L.-H. Antibacterial, anticancer and neuroprotective activities of rare Actinobacteria from mangrove forest soils. Indian J. Microbiol. 2017, 57, 177-187. [CrossRef] [PubMed]

47. Lee, L.-H.; Azman, A.-S.; Zainal, N.; Yin, W.-F.; Ab Mutalib, N.-S.; Chan, K.-G. Sinomonas humi sp. nov., an amylolytic actinobacterium isolated from mangrove forest soil. Int. J. Syst. Evol. Microbiol. 2015, 65, 996-1002. [CrossRef]

48. Lee, L.-H.; Azman, A.-S.; Zainal, N.; Eng, S.-K.; Ab Mutalib, N.-S.; Yin, W.-F.; Chan, K.-G. Microbacterium mangrovi sp. nov., an amylolytic actinobacterium isolated from mangrove forest soil. Int. J. Syst. Evol. Microbiol. 2014, 64, 3513-3519. [CrossRef]

49. Xie, Q.-Y.; Wang, C.; Wang, R.; Qu, Z.; Lin, H.-P.; Goodfellow, M.; Hong, K. Jishengella endophytica gen. nov., sp. nov., a new member of the family Micromonosporaceae. Int. J. Syst. Evol. Microbiol. 2011, 61, 1153-1159. [CrossRef]

50. Kohli, I.; Joshi, N.C.; Mohapatra, S.; Varma, A. Extremophile-an adaptive strategy for extreme conditions and applications. Curr. Genom. 2020, 21, 96-110. [CrossRef]

51. Merino, N.; Aronson, H.S.; Bojanova, D.P.; Feyhl-Buska, J.; Wong, M.L.; Zhang, S.; Giovannelli, D. Living at the extremes: Extremophiles and the limits of life in a planetary context. Front. Microbiol. 2019, 10, 780. [CrossRef] [PubMed]

52. Rampelotto, P.H. Extremophiles and Extreme Environments. Life 2013, 3, 482-485. [CrossRef] [PubMed]

53. Rothschild, L.J.; Mancinelli, R.L. Life in extreme environments. Nature 2001, 409, 1092-1101. [CrossRef] [PubMed]

54. Prieur, D. Extremophiles. In Encyclopedia of Astrobiology; Gargaud, M., Amils, R., Quintanilla, J.C., Cleaves, H.J., Irvine, W.M., Pinti, D.L., Viso, M., Eds.; Springer: Berlin/Heidelberg, Germany, 2011; pp. 572-575.

55. Pikuta, E.V.; Hoover, R.B.; Tang, J. Microbial extremophiles at the limits of life. Crit. Rev. Microbiol. 2007, 33, 183-209. [CrossRef] [PubMed]

56. Gholami, M.; Etemadifar, Z.; Bouzari, M. Isolation a new strain of Kocuria rosea capable of tolerating extreme conditions. J. Environ. Radioact. 2015, 144, 113-119. [CrossRef] [PubMed]

57. Des Marais, D.J.; Walter, M.R. Terrestrial hot spring systems: Introduction. Astrobiology 2019, 19, 1419-1432. [CrossRef] [PubMed]

58. Schmidt, T.M. Encyclopedia of Microbiology; Academic Press: San Diego, CA, USA, 2019.

59. Kristjansson, J.K. Thermophilic Bacteria; CRC Press: Boca Raton, FL, USA, 1991.

60. Singh, S.P.; Shukla, R.J.; Kikani, B.A. Molecular diversity and biotechnological relevance of thermophilic actinobacteria. In Thermophilic Microbes in Environmental and Industrial Biotechnology; Springer: Berlin/Heidelberg, Germany, 2013 ; pp. 459-479.

61. Liu, L.; Salam, N.; Jiao, J.-Y.; Jiang, H.-C.; Zhou, E.-M.; Yin, Y.-R.; Ming, H.; Li, W.-J. Diversity of culturable thermophilic actinobacteria in hot springs in Tengchong, China and studies of their biosynthetic gene profiles. Microb. Ecol. 2016, 72, 150-162. [CrossRef]

62. Hedlund, B.P.; Cole, J.K.; Williams, A.J.; Hou, W.; Zhou, E.; Li, W.; Dong, H. A review of the microbiology of the Rehai geothermal field in Tengchong, Yunnan Province, China. Geosci. Front. 2012, 3, 273-288. [CrossRef]

63. Dabbagh, R.; Ghafourian, H.; Baghvand, A.; Nabi, G.; Riahi, H.; Nakhli, A. Discovery of the second highest level of radioactive mineral spring in Iran. J. Radioanal. Nucl. Chem. 2006, 269, 91-94. [CrossRef]

64. Stahl, W.; Sies, H. Antioxidant activity of carotenoids. Mol. Asp. Med. 2003, 24, 345-351. [CrossRef]

65. Varma, S.; Shah, V.; Banerjee, B.; Buddhiraju, K.M. Change detection of desert sand dunes: A remote sensing approach. Adv. Remote Sens. 2014, 3, 10. [CrossRef]

66. Australian Bureau of Statistics. Year Book Australia, 1992 No. 75; Australian Bureau of Statistics: Canberra, Australia, 2003. Available online: shorturl.at/cvGX0 (accessed on 3 March 2021).

67. Makhalanyane, T.P.; Valverde, A.; Gunnigle, E.; Frossard, A.; Ramond, J.-B.; Cowan, D.A. Microbial ecology of hot desert edaphic systems. FEMS Microbiol. Rev. 2015, 39, 203-221. [CrossRef] [PubMed]

68. Logan, R.F. Causes, climates, and distribution of deserts. In Desert Biology: Special Topics on the Physical and Biological Aspects of Arid Regions; Academic Press: New York, NY, USA, 1968; Volume 1, pp. 21-50.

69. Schulz, D.; Beese, P.; Ohlendorf, B.; Erhard, A.; Zinecker, H.; Dorador, C.; Imhoff, J.F. Abenquines A-D: Aminoquinone derivatives produced by Streptomyces sp. strain DB634. J. Antibiot. 2011, 64, 763-768. [CrossRef] [PubMed]

70. Doran, P.T.; McKay, C.P.; Clow, G.D.; Dana, G.L.; Fountain, A.G.; Nylen, T.; Lyons, W.B. Valley floor climate observations from the McMurdo Dry Valleys, Antarctica, 1986-2000. J. Geophys. Res. Atmos. 2002, 107, ACL 13-11-ACL 13-12. [CrossRef]

71. Navarro-González, R.; Rainey, F.A.; Molina, P.; Bagaley, D.R.; Hollen, B.J.; de la Rosa, J.; Small, A.M.; Quinn, R.C.; Grunthaner, F.J.; Cáceres, L. Mars-like soils in the Atacama Desert, Chile, and the dry limit of microbial life. Science 2003, 302, $1018-1021$. [CrossRef]

72. Dandawate, P.; Vyas, A.; Padhye, S.; Singh, M.; Baruah, J. Perspectives on medicinal properties of benzoquinone compounds. Mini Rev. Med. Chem. 2010, 10, 436-454. [CrossRef]

73. Komatsu, K.; Lee, J.; Miyata, M.; Lim, J.H.; Jono, H.; Koga, T.; Xu, H.; Yan, C.; Kai, H.; Li, J. Inhibition of PDE4B suppresses inflammation by increasing expression of the deubiquitinase CYLD. Nat. Commun. 2013, 4, 1684. [CrossRef]

74. Bielekova, B.; Lincoln, A.; McFarland, H.; Martin, R. Therapeutic potential of phosphodiesterase-4 and-3 inhibitors in Th1mediated autoimmune diseases. J. Immunol. 2000, 164, 1117-1124. [CrossRef] 
75. Kumar, N.; Goldminz, A.M.; Kim, N.; Gottlieb, A.B. Phosphodiesterase 4-targeted treatments for autoimmune diseases. BMC Med. 2013, 11, 96. [CrossRef] [PubMed]

76. Rateb, M.E.; Houssen, W.E.; Arnold, M.; Abdelrahman, M.H.; Deng, H.; Harrison, W.T.; Okoro, C.K.; Asenjo, J.A.; Andrews, B.A.; Ferguson, G. Chaxamycins A-D, bioactive ansamycins from a hyper-arid desert Streptomyces sp. J. Nat. Prod. 2011, 74, 1491-1499. [CrossRef] [PubMed]

77. Hostein, I.; Robertson, D.; DiStefano, F.; Workman, P.; Clarke, P.A. Inhibition of signal transduction by the Hsp90 inhibitor 17-allylamino-17-demethoxygeldanamycin results in cytostasis and apoptosis. Cancer Res. 2001, 61, 4003-4009. [PubMed]

78. Wichner, D.; Idris, H.; Houssen, W.E.; McEwan, A.R.; Bull, A.T.; Asenjo, J.A.; Goodfellow, M.; Jaspars, M.; Ebel, R.; Rateb, M.E. Isolation and anti-HIV-1 integrase activity of lentzeosides A-F from extremotolerant Lentzea sp. H45, a strain isolated from a high-altitude Atacama Desert soil. J. Antibiot. 2017, 70, 448-453. [CrossRef]

79. Smith, S.J.; Zhao, X.Z.; Burke, T.R.; Hughes, S.H. HIV-1 integrase inhibitors that are broadly effective against drug-resistant mutants. Antimicrob. Agents Chemother. 2018, 62, e00611-20. [CrossRef] [PubMed]

80. Nithya, K.; Muthukumar, C.; Biswas, B.; Alharbi, N.S.; Kadaikunnan, S.; Khaled, J.M.; Dhanasekaran, D. Desert actinobacteria as a source of bioactive compounds production with a special emphases on Pyridine-2, 5-diacetamide a new pyridine alkaloid produced by Streptomyces sp. DA3-7. Microbiol. Res. 2018, 207, 116-133. [CrossRef]

81. Noreen, N.; Ramzan, N.; Perveen, Z.; Shahzad, S. A comparative study of cow dung compost, goat pellets, poultry waste manure and plant debris for thermophilic, thermotolerant and mesophilic microflora with some new reports from Pakistan. Pak. J. Bot. 2019, 51, 1155-1159. [CrossRef]

82. Ahmed, Z.; Sedik, Z.; Alharery, M.; Khalaf, M.; Nasr, S.A.; Abdelrahman, H. Microbial ecology of composting dead poultry and their wastes. Glob. Vet. 2012, 9, 683-690.

83. Wölfl, A.-C.; Snaith, H.; Amirebrahimi, S.; Devey, C.W.; Dorschel, B.; Ferrini, V.; Huvenne, V.A.; Jakobsson, M.; Jencks, J.; Johnston, G. Seafloor Mapping-the challenge of a truly global ocean bathymetry. Front. Mar. Sci. 2019, 6, 283. [CrossRef]

84. Mestre, N.C.; Calado, R.; Soares, A.M. Exploitation of deep-sea resources: The urgent need to understand the role of high pressure in the toxicity of chemical pollutants to deep-sea organisms. Environ. Pollut. 2014, 185, 369-371. [CrossRef]

85. Dalmaso, G.Z.L.; Ferreira, D.; Vermelho, A.B. Marine extremophiles: A source of hydrolases for biotechnological applications. Mar. Drugs 2015, 13, 1925-1965. [CrossRef]

86. Sarmiento-Vizcaíno, A.; González, V.; Braña, A.F.; Palacios, J.J.; Otero, L.; Fernández, J.; Molina, A.; Kulik, A.; Vázquez, F.; Acuña, J.L. Pharmacological potential of phylogenetically diverse Actinobacteria isolated from deep-sea coral ecosystems of the submarine Avilés Canyon in the Cantabrian Sea. Microb. Ecol. 2017, 73, 338-352. [CrossRef] [PubMed]

87. Li, Q.Q.; Lee, R.X.; Liang, H.; Zhong, Y. Anticancer activity of $\beta$-elemene and its synthetic analogs in human malignant brain tumor cells. Anticancer Res. 2013, 33, 65-76. [PubMed]

88. Zhang, G.-N.; Ashby, C.R.; Zhang, Y.-K.; Chen, Z.-S.; Guo, H. The reversal of antineoplastic drug resistance in cancer cells by $\beta$-elemene. Chin. J. Cancer 2015, 34, 45. [CrossRef] [PubMed]

89. Naik, P.M.; Al-Khayri, J.M. Abiotic and biotic elicitors-role in secondary metabolites production through in vitro culture of medicinal plants. In Abiotic and Biotic Stress in Plants-Recent Advances and Future Perspectives; InTech: Rijeka, Croatia, 2016; pp. 247-277.

90. Xu, D.; Han, L.; Li, C.; Cao, Q.; Zhu, D.; Barrett, N.H.; Harmody, D.; Chen, J.; Zhu, H.; McCarthy, P.J. Bioprospecting deep-sea actinobacteria for novel anti-infective natural products. Front. Microbiol. 2018, 9, 787. [CrossRef]

91. Cohen, S.H.; Gerding, D.N.; Johnson, S.; Kelly, C.P.; Loo, V.G.; McDonald, L.C.; Pepin, J.; Wilcox, M.H. Clinical practice guidelines for Clostridium difficile infection in adults: 2010 update by the society for healthcare epidemiology of America (SHEA) and the infectious diseases society of America (IDSA). Infect. Control Hosp. Epidemiol. 2010, 31, 431-455. [CrossRef]

92. Northup, D.E.; Lavoie, K.H. Geomicrobiology of caves: A review. Geomicrobiol. J. 2001, 18, 199-222.

93. Gillieson, D. Caves: Processes, Development and Management; John Wiley \& Sons: Hoboken, NJ, USA, 2009.

94. Howard, A.D. Processes of limestone cave development. Int. J. Speleol. 1964, 1, 8. [CrossRef]

95. Pelletier, B. Empire Biota: Taxonomy and Evolution, 2nd ed.; Lulu.com: Morrisville, CA, USA, 2012. Available online: shorturl.at/ cvGX0 (accessed on 3 March 2021).

96. Maciejewska, M.; Adam, D.; Naômé, A.; Martinet, L.; Tenconi, E.; Całusińska, M.; Delfosse, P.; Hanikenne, M.; Baurain, D.; Compère, P. Assessment of the potential role of Streptomyces in cave moonmilk formation. Front. Microbiol. $2017,8,1181$. [CrossRef] [PubMed]

97. Adam, D.; Maciejewska, M.; Naômé, A.; Martinet, L.; Coppieters, W.; Karim, L.; Baurain, D.; Rigali, S. Isolation, characterization, and antibacterial activity of hard-to-culture actinobacteria from cave moonmilk deposits. Antibiotics 2018, 7, 28. [CrossRef]

98. Pardo-Igúzquiza, E.; Dowd, P.A.; Xu, C.; Durán-Valsero, J.J. Stochastic simulation of karst conduit networks. Adv. Water Resour. 2012, 35, 141-150. [CrossRef]

99. Ford, D.; Williams, P.D. Karst Hydrogeology and Geomorphology; John Wiley \& Sons: Hoboken, NJ, USA, 2013.

100. Long, Y.; Jiang, J.; Hu, X.; Zhou, J.; Hu, J.; Zhou, S. Actinobacterial community in Shuanghe Cave using culture-dependent and-independent approaches. World J. Microbiol. Biotechnol. 2019, 35, 153. [CrossRef]

101. Vertesy, L.; Ehlers, E.; Kogler, H.; Kurz, M.; Meiwes, J.; Seibert, G.; Vogel, M.; Hammann, P. Friulimicins: Novel Lipopeptide Antibiotics with Peptidoglycan Synthesis Inhibiting Activity from Actinoplanes friuliensis sp. nov. J. Antibiot. 2000, 53, 816-827. [CrossRef] 
102. Baxter, B.K. Great Salt Lake microbiology: A historical perspective. Int. Microbiol. 2018, 21, 79-95. [CrossRef]

103. Last, W.M. Geolimnology of salt lakes. Geosci. J. 2002, 6, 347-369. [CrossRef]

104. Albarracín, V.H.; Pathak, G.P.; Douki, T.; Cadet, J.; Borsarelli, C.D.; Gärtner, W.; Farias, M.E. Extremophilic Acinetobacter strains from high-altitude lakes in Argentinean Puna: Remarkable UV-B resistance and efficient DNA damage repair. Orig. Life Evol. Biosph. 2012, 42, 201-221. [CrossRef] [PubMed]

105. Rasuk, M.C.; Ferrer, G.M.; Kurth, D.; Portero, L.R.; Farías, M.E.; Albarracín, V.H. UV-resistant actinobacteria from high-altitude Andean Lakes: Isolation, characterization and antagonistic activities. Photochem. Photobiol. 2017, 93, 865-880. [CrossRef] [PubMed]

106. Zhang, M.; Wang, L.; Zhong, D. Photolyase: Dynamics and mechanisms of repair of sun-induced DNA damage. Photochem. Photobiol. 2017, 93, 78-92. [CrossRef] [PubMed]

107. Wu, J.; Peng, Z.; Guan, T.-W.; Yang, H.; Tian, X. Diversity of actinobacteria in sediments of Qaidam Lake and Qinghai Lake, China. Arch. Microbiol. 2021, 1-11. [CrossRef]

108. Mohammadipanah, F.; Wink, J. Actinobacteria from arid and desert habitats: Diversity and biological activity. Front. Microbiol. 2016, 6, 1541. [CrossRef]

109. Crits-Christoph, A.; Robinson, C.K.; Barnum, T.; Fricke, W.F.; Davila, A.F.; Jedynak, B.; McKay, C.P.; DiRuggiero, J. Colonization patterns of soil microbial communities in the Atacama Desert. Microbiome 2013, 1, 28. [CrossRef]

110. Grossart, H.-P.; Schlingloff, A.; Bernhard, M.; Simon, M.; Brinkhoff, T. Antagonistic activity of bacteria isolated from organic aggregates of the German Wadden Sea. FEMS Microbiol. Ecol. 2004, 47, 387-396. [CrossRef]

111. Zeng, Q.; Huang, H.; Zhu, J.; Fang, Z.; Sun, Q.; Bao, S. A new nematicidal compound produced by Streptomyces albogriseolus HA10002. Antonie Van Leeuwenhoek 2013, 103, 1107-1111. [CrossRef]

112. Zhang, W.; Wei, S.; Zhang, J.; Wu, W. Antibacterial activity composition of the fermentation broth of Streptomyces djakartensis NW35. Molecules 2013, 18, 2763-2768. [CrossRef]

113. Kumar, P.S.; Yuvaraj, P.; Paulraj, M.G.; Ignacimuthu, S.; Al-Dhabi, N.A. Bio-Prospecting of soil Streptomyces and its bioassay-guided isolation of microbial derived auxin with antifungal properties. J. Mycol. Med. 2018, 28, 462-468. [CrossRef] [PubMed]

114. Mbah, J.A.; Ngemenya, M.N.; Abawah, A.L.; Babiaka, S.B.; Nubed, L.N.; Nyongbela, K.D.; Lemuh, N.D.; Efange, S.M. Bioassayguided discovery of antibacterial agents: In vitro screening of Peperomia vulcanica, Peperomia fernandopoioana and Scleria striatinux. Ann. Clin. Microbiol. Antimicrob. 2012, 11, 10. [CrossRef] [PubMed]

115. Steinbeck, C.; Kuhn, S. NMRShiftDB-compound identification and structure elucidation support through a free community-built web database. Phytochemistry 2004, 65, 2711-2717. [CrossRef]

116. Law, J.W.-F.; Chan, K.-G.; He, Y.-W.; Khan, T.M.; Ab Mutalib, N.-S.; Goh, B.-H.; Lee, L.-H. Diversity of Streptomyces spp. from mangrove forest of Sarawak (Malaysia) and screening of their antioxidant and cytotoxic activities. Sci. Rep. 2019, 9, 1-15. [CrossRef] [PubMed]

117. Gosse, J.T.; Ghosh, S.; Sproule, A.; Overy, D.; Cheeptham, N.; Boddy, C.N. Whole genome sequencing and metabolomic study of cave Streptomyces isolates ICC1 and ICC4. Front. Microbiol. 2019, 10, 1020. [CrossRef]

118. Ser, H.-L.; Ab Mutalib, N.-S.; Yin, W.-F.; Goh, B.-H.; Lee, L.-H.; Chan, K.-G. Genome sequence of Streptomyces antioxidans MUSC $164^{\mathrm{T}}$ isolated from mangrove forest. Prog. Microbes Mol. Biol. 2018, 1, a0000001. [CrossRef]

119. Ōmura, S.; Ikeda, H.; Ishikawa, J.; Hanamoto, A.; Takahashi, C.; Shinose, M.; Takahashi, Y.; Horikawa, H.; Nakazawa, H.; Osonoe, T. Genome sequence of an industrial microorganism Streptomyces avermitilis: Deducing the ability of producing secondary metabolites. Proc. Natl. Acad. Sci. USA 2001, 98, 12215-12220. [CrossRef] [PubMed]

120. Lee, N.; Kim, W.; Hwang, S.; Lee, Y.; Cho, S.; Palsson, B.; Cho, B.-K. Thirty complete Streptomyces genome sequences for mining novel secondary metabolite biosynthetic gene clusters. Sci. Data 2020, 7, 1-9. [CrossRef]

121. Ser, H.-L.; Chan, K.-G.; Tan, W.-S.; Yin, W.-F.; Goh, B.-H.; Ab Mutalib, N.-S.; Lee, L.-H. Complete genome of mangrove-derived anti-MRSA streptomycete, Streptomyces pluripotens MUSC 135 . Prog. Microbes Mol. Biol. 2018, 1, a0000004. [CrossRef]

122. Ser, H.-L.; Law, J.W.-F.; Tan, W.-S.; Yin, W.-F.; Chan, K.-G.; Lee, L.-H. Genome sequence of bioactive streptomycete isolated from mangrove forest in East Malaysia, Streptomyces monashensis MUSC 1J ${ }^{\mathrm{T}}$. Prog. Drug Discov. Biomed. Sci. 2019, 2, a0000045. [CrossRef]

123. Ser, H.-L.; Law, J.W.-F.; Tan, W.-S.; Yin, W.-F.; Chan, K.-G. Whole genome sequence of Streptomyces colonosanans strain MUSC 93J ${ }^{\mathrm{T}}$ isolated from mangrove forest in Malaysia. Prog. Microbes Mol. Biol. 2020, 3, a0000061. [CrossRef]

124. Ser, H.-L.; Tan, W.-S.; Ab Mutalib, N.-S.; Cheng, H.-J.; Yin, W.-F.; Chan, K.-G.; Lee, L.-H. Genome sequence of Streptomyces pluripotens MUSC $135^{\mathrm{T}}$ exhibiting antibacterial and antioxidant activity. Mar. Genom. 2015, 24, 281-283. [CrossRef] [PubMed]

125. Ser, H.-L.; Tan, W.-S.; Cheng, H.-J.; Yin, W.-F.; Chan, K.-G.; Ab Mutalib, N.-S.; Goh, B.-H.; Lee, L.-H. Draft genome of starchdegrading actinobacterium, Microbacterium mangrovi MUSC $115^{\mathrm{T}}$ isolated from intertidal sediments. Prog. Drug Discov. Biomed. Sci. 2018, 1, a0000005. [CrossRef]

126. Li, S.; Li, Y.; Lu, C.; Zhang, J.; Zhu, J.; Wang, H.; Shen, Y. Activating a cryptic ansamycin biosynthetic gene cluster to produce three new naphthalenic octaketide ansamycins with n-pentyl and n-butyl side chains. Org. Lett. 2015, 17, 3706-3709. [CrossRef] [PubMed] 